\title{
Lietuvos vietinių galvijų paplitimo ir produktyvumo analizè
}

\section{Lina Anskienè}

Lietuvos sveikatos moksly universitetas, Veterinarijos akademija, Gyvūnu veisimo katedra, Tilžès g. 18, LT-47181 Kaunas El.paštas:anskiene@lva.lt.
Lietuvos ūkinių gyvūnų genetiniai ištekliai yra nacionalinis turtas, kuris turi selekcinę, ekonominę, mokslinę, ekologinę, kultūrinę, istorinę reikšmę Lietuvos Respublikai ir yra svarbi pasaulinės biologinès ịvairovès dalis. Dél sparčios žemès ūkio plètros ir pokyčių rinkos ekonomikos erdvèje labai aukšto produktyvumo specializuotos žemės ūkio gyvulių ir paukščiu veislès išstūmė vietines, kurios ir atsidūre ties išnykimo riba. Buvo imtasi ̨̇vairių iniciatyvų išsaugoti senąsias gyvulių veisles nuo visiško išnykimo.

Tyrimo tikslas - išanalizuoti kontroliuojamų Lietuvos vietinių, genofondinių baltnugarių ir šèmųjų karvių paplitimą bei produktyvumą.

Pagal įvairias programas laikantiems senųjų veislių gyvulių ir paukščiu mokamos kompensacinès išmokos. Taip ūkininkams atlyginami nuostoliai, kuriuos jie gali patirti dèl mažesnio senujjų veislių, tarp jų vietinių baltnugarių ir šemųjų produktyvumo. Tačiau Lietuvos baltnugarių ir šemujų galvijų paplitimas ir gyvulių laikytojų (ūkių skaičius) mažai didèja. 2004-2010 m. kontroliuojamų Lietuvos baltnugarių ir šèmųjų karvių skaičius šalyje padidèjo 0,9 karto.

Kontroliuojamos Lietuvos baltnugarès karvès sudaro 0,21\%,Lietuvos šèmosios - 0,25\% (kontroliuojamų karvių atžvilgiu). Analizès rezultatai parodè, kad vietiniai Lietuvos baltnugariai ir šèmieji galvijai daugiausia (66-67 \%) sutinkami pavienių gyvulių augintojų ūkiuose, kur laikoma vidutiniškai po 1-2 karves.

Tiriamuoju laikotarpiu Lietuvos baltnugarès karvès atsiliko pieningumu 3,78-12,01 \%, pieno riebalų produkcija - 5,96-11,48 \%, pieno baltymu kiekiu - 4,95-13,04 \%, palyginti su šalies kontroliuojamų karvių vidurkiu. Lietuvos šèmųjų kontroliuojamų karvių primilžis buvo 4,89-10,81 \% mažesnis nei visų kontroliuojamų karvių vidurkis, pieno riebalų gauta 7,66-14,07 \% ir pieno baltymų $-6,04-12,08 \%$ mažiau.

Lietuvos šèmujjų karvių primilžiai didèjo tolygiai - nuo $5131 \mathrm{~kg}$ padidèjo $407 \mathrm{~kg}\left(y=87,371 x+5087,2 ; R^{2}=0,879\right)$. Nors Lietuvos baltnugarių karvių pieningumas analizuojamu laikotarpiu padidèjo $272 \mathrm{~kg}$, tačiau didèjimas nebuvo toks tolygus, kaip šèmụjų karvių $\left(y=64,829 x+5165,9 ; R^{2}=0,616\right)$.

Lietuvos baltnugarių ir šemujų karvių produktyvumas, palyginti su kitu šaliu vietinėmis veislėmis, artimiausias Latvijos žalųjų galvijų veislei.

Raktažodžiai: Lietuvos baltnugariai, Lietuvos šèmieji, paplitimas, produktyvumas

\section{IVADAS}

Sparti žemės ūkio plètra ir pokyčiai rinkos ekonomikos erdvèje lèmé, kad vietines žemès ūkio gyvulių ir paukščiu veisles išstūmè labai aukšto produktyvumo specializuotos veislès. Senosios gyvulių veislès atsidūrè ties išnykimo riba, todèl buvo imtasi ịvairių iniciatyvų išsaugoti jas nuo visiško išnykimo (Hall, 1993).

Biologinès îvairovès konvencija, kurią Lietuva kartu su kitomis pasaulio valstybemis pasirašè $1992 \mathrm{~m}$., o 1996 m. ratifikavo Seime, pabrèžia žemès ūkio 
gyvūnų genetinès ịvairovès reikšmę bendrai pasaulo biologinei ivairovei ir ipareigoja pasirašiusias šalis saugoti savo genetinius išteklius. Rǔšiu genetini kintamumą, be kurio būtu neịmanoma evoliucija, didele dalimi praturtina ir išlaiko egzistuojanti veislių ịvairovè (Lietuvos žemès ūkio ministerija, 2003; Lietuvos ūkinių gyvūnų augintojų asociacija, 2008; Lietuvos gyvulininkystés institutas, 2011 ).

Lietuvos ūkinių gyvūnų genetiniai ištekliai yra nacionalinis turtas, kuris turi selekcinę, ekonominę, mokslinę, ekologinę, kultūrinę, istorinę svarbą Lietuvos Respublikai ir yra svarbi pasaulinès žemès ūkio ịvairovès ir visos biologinès ịvairovè dalis (Lietuvos gyvulininkystès institutas, 2011).

Senosios vietinès Lietuvos žemès ūkio gyvūnu veislès buvo mažai tyrinètos, todèl buvo pradèti jų biologiniu-ūkiniu savybiu ir genetinès ịvairovès tyrimai (Kuosa, 1980). Vietinès galvijų veislès yra svarbios ne tik ekonominiu, bet ir istoriniu požiūriu, kadangi kiekviena veislè turi savo unikalu evoliucijos kelią (Malevičiūté, 2002; Värv, 2004).

Lietuvos baltnugariu ir šèmuju galviju veislés yra żinomos jau nuo XX a. pirmosios pusés, tačiau ilgą laiką ivvairiu juodmargiu bei žalmargiu veislès nekontroliuojamai buvo gerinamos buliais, masiškai brokuojamos dideliu ùkiu bandos dèl netinkamos spalvos, o neatsižvelgiama ị produktyvuma ir dèl daugelio ekonominių veiksnių, šios veislès atsidūrè ant išnykimo ribos (Lietuvos žemès ūkio ministerija, 2003).

Tyrimo tikslas. Išanalizuoti kontroliuojamụ vietinių, genofondiniu Lietuvos baltnugarių ir šèmuju karvių paplitimą, jų produktyvumą.

Tyrimu metodai ir sąlygos. Analizuojant vietini Lietuvos baltnugarių ir šemụjų populiacijų karvių produktyvumą naudoti Lietuvos kontroliuojamy karviu bandu produktyvumo 2004-2010 m. apyskaity duom KVC) duomenu baze.

Vietiniu galviju paplitimas rajonuose buvo tirtas ịvertinus ir išanalizavus 820 Lietuvos baltnugarių, 1775 šėmuju grynaveisliụ, mišrūniu karvių ir telyčių trijų kartų kilmę. Remiantis šiais duomenimis, buvo sudaryti vietinių veislių galviju paplitimo žemèlapiai. Sudarant naudotasi ŽÜIKVC veislių klasifikatoriumi, pagal kurị 91 kodas - Lietuvos baltnugarių, 92 - Lietuvos šèmuju galvijų veislès.

Statistiniai duomenys apibendrinti skaičiuokle s Excel ir SPSS (licencijos Nr. 9900457; versija 15,
SPSS Inc., Chicago, IL) statistiniu paketu, ivvertint koreliacinè ir funkcinè priklausomybe tarp tiriamuju požymių. Rezultatai laikyti patikimais, ka $\mathrm{p}<0,05$

\section{TYRIMŲ REZULTATAI IR APTARIMAS}

Lietuvos baltnugarių veislè žinoma nuo senų laiku oXX a pr. sudare $10 \%$ visy šalies galviju Ilog laika Lietuvos baltnugariai buvo gerinami ivairi juodmargiu bei žalmargiu veisliu buliais (Šveistiené, Anskienè, 2011)

Yra žinoma, kad baltnugariai galvijai taip pat buvo auginami ir yra išlikę iki šių dienų Šiaurés Rytų Lenkijoje ir Skandinavijos šalyse bei kai kuriuose Rusijos regionuose. Lietuvoje baltnugariai galvijai dažniausiai buvo sutinkami centrinèje dalyje, pietryčiu ir pietvakarių rajonuose (Kuosa 1980; Tušas ir kt., 2000; Litwinczuk, 2002; Lietuvos žemès ūkio ministerija, 2003; Šveistienè et al. 2008; Kauryniené et al., 2011).

Analizès duomenimis, vietiniai baltnugariai galvijai daugiausia sutinkami pavieniy gyvuliy auu, Kedainiu, Varènos, Kaišiadoriu rajonuose laikoma iki 5 vietiniu baltnugariụ grynaveislių karviụ / telyčiù Kauno Jurbarko, Tauragès - 6-9; Šakių, Prienų Vilniau Radviliškio, Telšių - 11-20 karvių / telyčių; Šilalès Marijampolès, Alytaus, Lazdijų rajonuose - 21 ir daugiau (1 pav.)

Vietiniu baltnugariu grynaveisliu ir mišrūniu karviụ / telyčių Vilkaviškio, Varėnos, Kaišiadoriu Šilutès, Kretingos, Plungès, Mažeikių, Joniškio, Pakruojo, Panevėžio, Utenos, Raseinių rajonuose laikoma 1-5; Siaulių, Kauno - 6-10; Tauragès, urbarko, Kèdainiu - 11-20; Telšiu, Radviliškio, Sakiu, Prienu, Marijampolès, Lazdiju Salčininkt, Vilniaus - 20-100; Alytaus, Šilalès rajonuose - 101 ir daugiau (2 pav.)

Panašias Lietuvos baltnugarių galvijų paplitimo tendencijas aprašè ir J. Šveistys (1998).

J. Kuosa (1980) taip pat pastebèjo, kad pavieniu vietiniu galviju daugiausia išliko pas privacius asmenis, tačiau vargu ar kur nors išliko vietiniu galvijy su pirmy v̌cinis požymigis, nes visur jie daugiau ar mažiau susimaišè su užsieniniais galvijais.

Lietuvos šemųjų veislè žinoma nuo XVI a. ki mūsų dienų, galvijai išlaikè būdingą spalvą bei ükines savybes. Semieji galvijai gali buti nuo

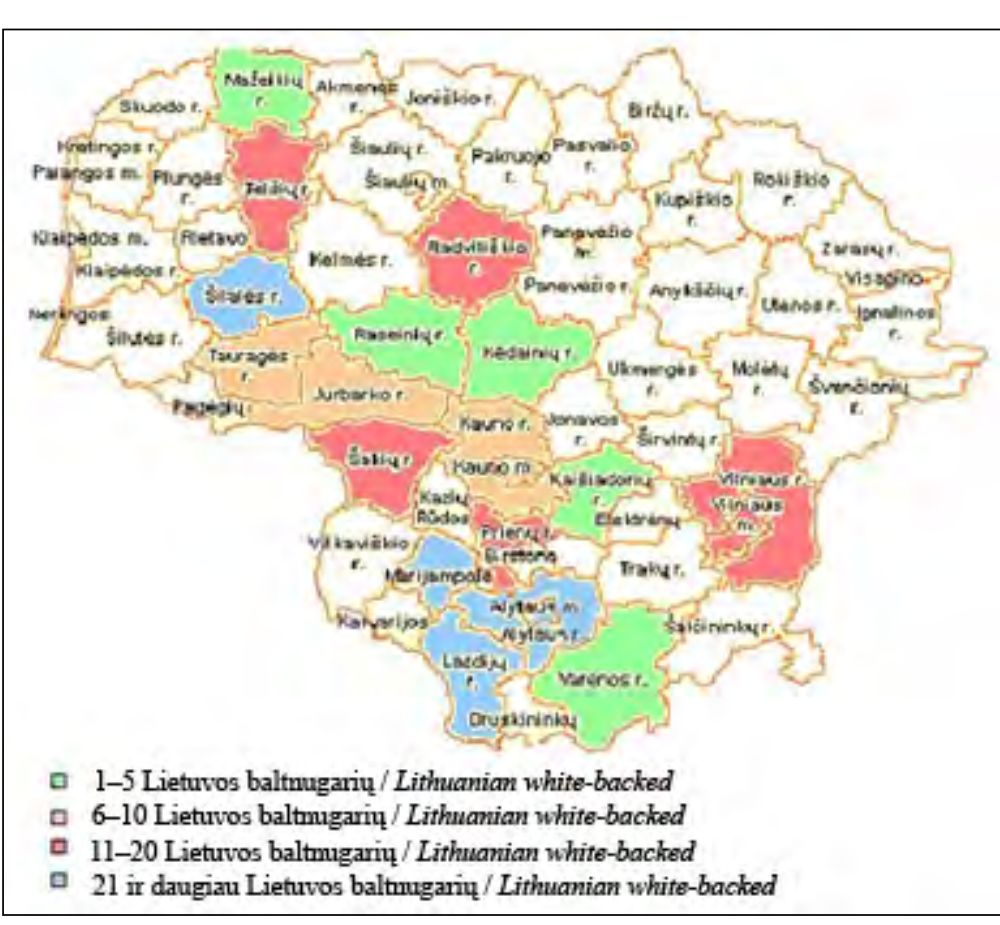

pav. Lietuvos baltnugarių karviụ ir telyčiu skaičius pagal rajonus kai pati karvè ir jos tèvai atitinka veislę (grynaveislès) Fig. 1. The number of Lithuanian White-backed cows / heifers by districts (pure-breed)

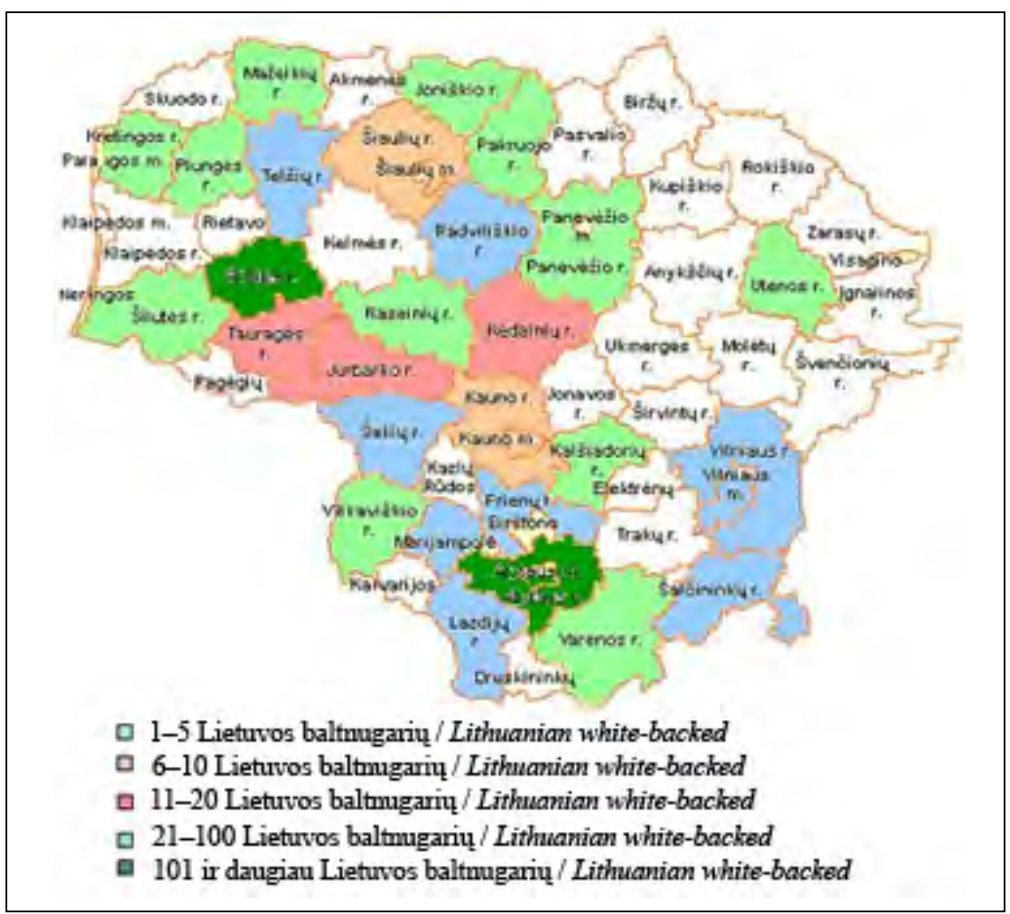

2 pav. Lietuvos baltnugarių karvių ir telyčį̣ (grynaveislių ir mišrūniu kartu) skaicius pagal rajonus $2010 \mathrm{~m}$.

Fig. 2. The number of Lithuanian White-backed cows / heifers by disricts in 2010 (pure-breed and crosses) 
pilkai melsvos iki pelenų pilkos spalvos, kai kurių Marijampolès, Prienų, Vilkaviškio, Šakių, Kaugyvulių kojos ir galvos yra baltos. Galvijų augin- no, Jurbarko, Kèdainių, Utenos, Radviliškio, Ši rams, ramaus būdo, gera pieno kokybè, nereiklūs
laikymo salygoms, gyvybingi (Šveistienè, Anskielaikymo są)

Vietiniu šèmujų grynaveisliu karvių / telyčių Plungès, Tauragès, Rokiškio, Anykščiu, Kèdainiu jonuose laikoma 1-5; Skuodo, Jurbarko, Prienų, Vilniaus - 6-10; Kretingos, Telšių, Radviliškio, Kauno - 11-20; Šilalès, Šakių, Vilkaviškio, Marijampoles, Alytaus, Lazdijų, Utenos rajonuose -21 ir daugiau ( 3 pav.)

Nustatème, kad vietiniu šèmuju grynaveisliu

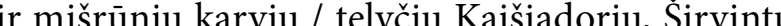
Molètu, Ignalinos, Anykščiu, Panevežio, Šiaulių Mažeikių, Tauragès, Šilutès, Klaipèdos rajonuose laikoma 1-5; Rietavo, Pagègių, Kalvarijos, Ukmergès - 6-10; Varènos, Šalčininkų, Trakų, Vilniaus, Raseiniu, Kelmès, Rokiškio, Skuodo - 11-20; alès, Telšiu, Plungès, Kretingos - 21-100; Lazdiju, Alytaus rajonuose - nuo 101 ir daugiau (4 pav.)

Pavieniu gyvulių augintoju ūkiuose, kuriuose aikoma po vieną ar dvi karves, kontroliuojamu deja, tik maža dalis.

Siekiant išsaugoti vietiniu galviju genofonda prof. J. Kuosos ir prof. J. Šveisčio iniciatyva buvo suformuotos šèmuju ir baltnugariu galviju reliktinès-genofondinès bandos, kuriose gyvuliai veisiami grynuoju veisimu, tiriamos jų biologinès-ūkinès savybès (Lietuvos senụjų vietinių žemés ūkio gyvūnų genetinių išteklių išsaugojimo programa, 1997; Šveistienè ir kt., 2008).

M. A. Quddus (2010) pažymi, kad vietinia galvijai vertingi, nes yra sveiki, puikiai prisitaike prie gamtinių ir klimato sąlygų, atsparūs ịvairioms ligoms, nereiklūs šèrimo ir laikymo sąlygoms, gyvybingi ir ilgaamžiai, pasižymi geromis reprodukcinemis savybemis.

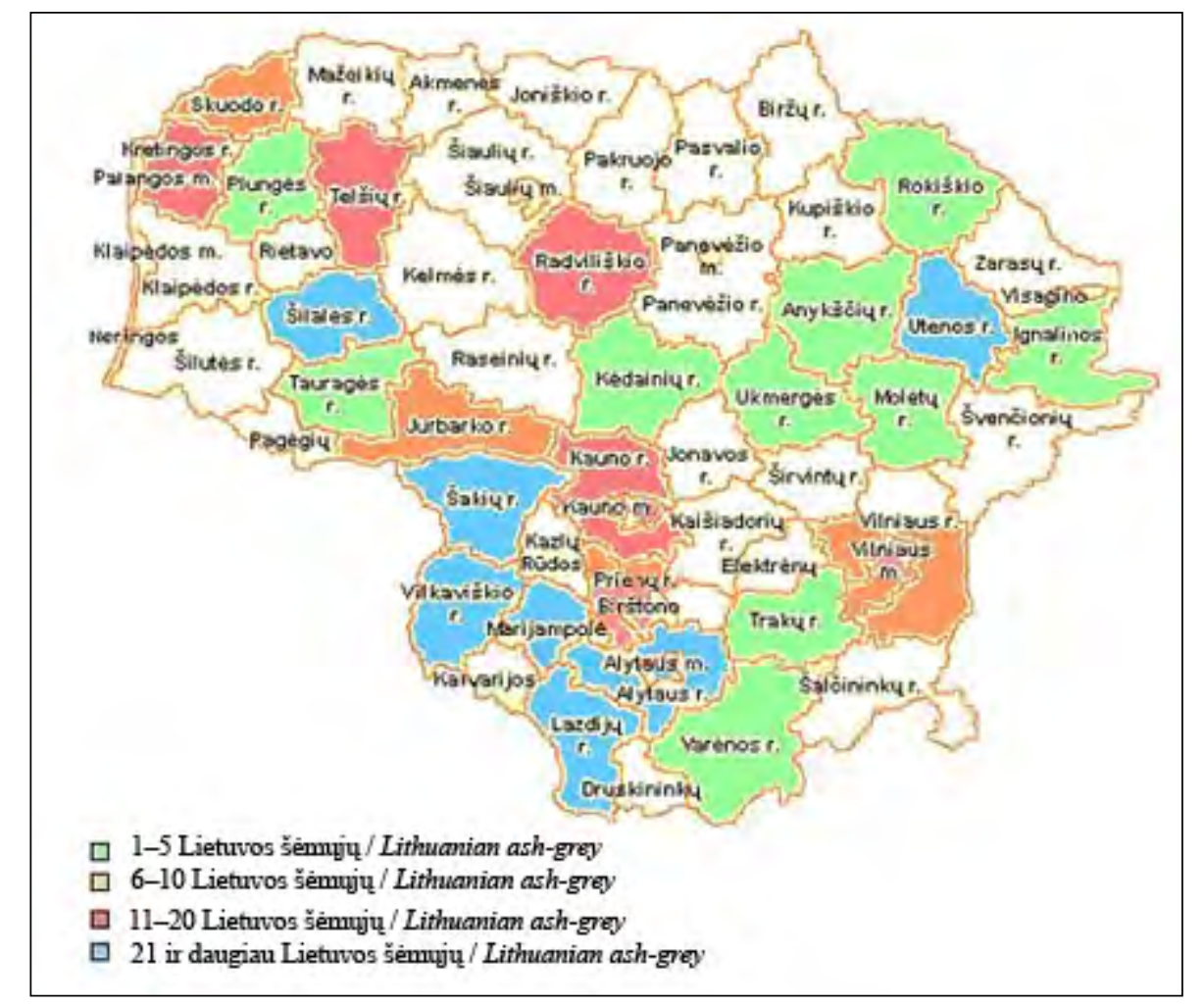

3 pav. Lietuvos šèmujjų karvių ir telyčių skaičius pagal rajonus, kai pati karve ir jos tèvai atitinka veislés reikalavimus

Fig. 3. The number of Lithuanian Ash-grey cows / heifers by districts (pure-breed)

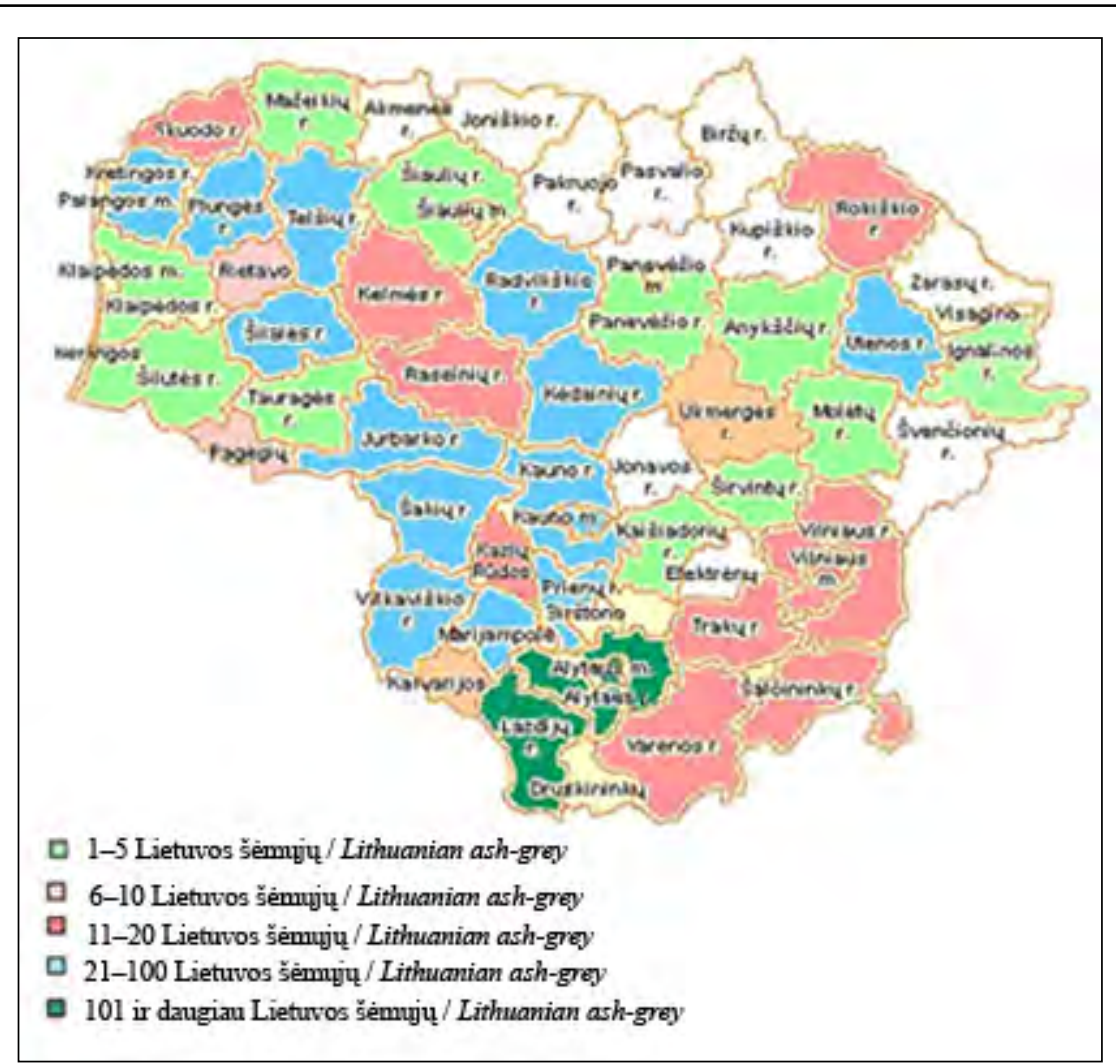

4 pav. Lietuvos šèmuju karviụ ir telyčiu (grynaveisliụ ir mišrūniu kartu) skaičius pagal rajonus Fig. 4. The nuber Lithuanian Ash-grey cows / heifers by districts (pure-breed and crosses)

Lietuvos genofondinis ūkinis gyvūnas - Lietuvos geografineje ūkinèje aplinkoje susidariusios atkuriamos ir palaikomos populiacijos arba veislès su būdingais požymiais ir ypatybèmis gyvūnas, itrauktas ị savo populiacijos išsaugojimo programą (Lietuvos ūkinių gyvūnų genetinių išteklių išsaugojimo programa, 2008)

Ilgą laiką tarptautinès veisimo programos buvo orientuotos intensyviai didinti galviju produktyvumą, o šis procesas lèmé ekonominę konkurenciją tarp komercini mažejo pastaruju paplitimas ir skaiciur čiūtè, 2002; Juškienè, 2003; Grigaliūnaitè, 2004 Bondesan et al., 2011).

Lietuvos baltnugares kontroliuojamos karvès sudaro $0,32 \%$, Lietuvos šèmosios - 0,37 \% kitų veisliu kontroliuojamų karvių atžvilgiu (Kontroliuojamu karviu bandu produktyvumo apyskaita, 2008; 2010).

Nors daugelis vietiniu galviju veislių karviu yra mažiau pieningos, palyginti su plataus paplitimo veislèmis (holšteinai ir kt.), tačiau yra ne tik gera prisitaikiusios prie gamtiniu ir klimatiniu sąlygu bet pasižymi vertingomis bei savitomis fenotipinèmis ir genetinèmis savybèmis (Malevičiūté, 2002 Quddus et al., 2010).

Tiriamuoju laikotarpiu Lietuvos baltnugarè karvès atsiliko pieningumu 3,78-12,01\%, pieno riebalų produkcija - 5,96-11,48\%, pieno baltymu kiekiu - 4,95-13,04 \%, palyginti su šalies kontrohuojamu karviu vidurkiu (5 pav.)

Lietuvos šèmujų kontroliuojamu karviu primilžis buvo $4,89-10,81 \%$ mažesnis nei visų kontroliuojamu karviu vidurkis, pieno riebalu gauta 7,66-14,07 \% ir pieno baltymu - 6,04-12,08 \% mažiau (6 pav.)

Tyrimo metu gauti duomenys (5 ir 6 pav.) rodo, kad Lietuvos baltnugariu ir semuju karvi produktyvumo skirtumas su salies kontroliuojamu karviu vidurkiu kasmet dideja. Akivaizdu, kad Lietuvoje vykdoma kryptinga kitu veisliu galviju selekcija siekiant pieningumo, pieno riebumo ir pieno baltymingumo.

Vietinès nykstančios baltnugarès ir šèmosio karvès veisiamos grynuoju būdu išsaugant veislei 


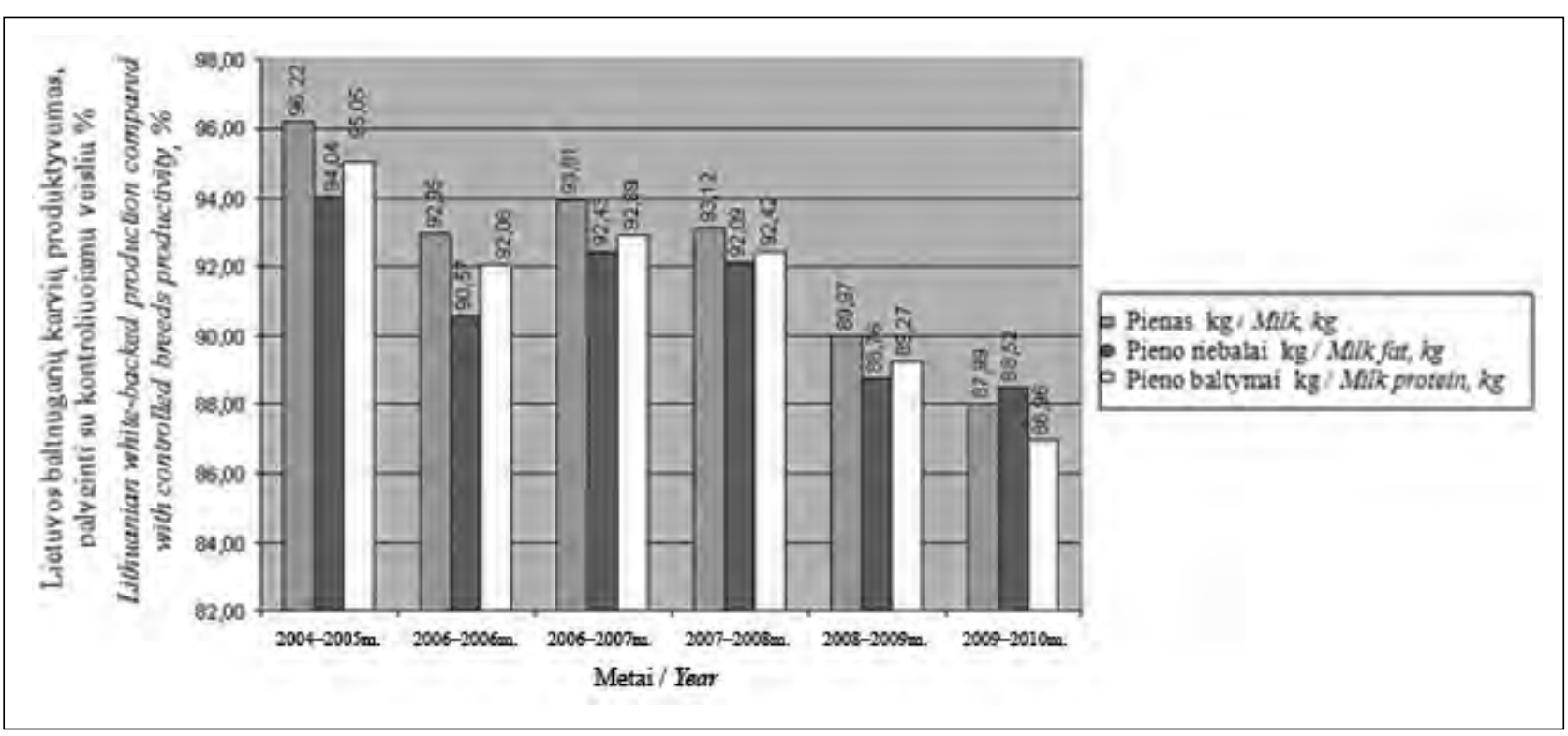

5 pav. Lietuvos baltnugariu produktyvumo palyginimas su kontroliuojamų karvių vidurkiu

Fig. 5. Comparison of productivity of Lithuanian White-backed cows with the average productivity of all controlled cows (\%)

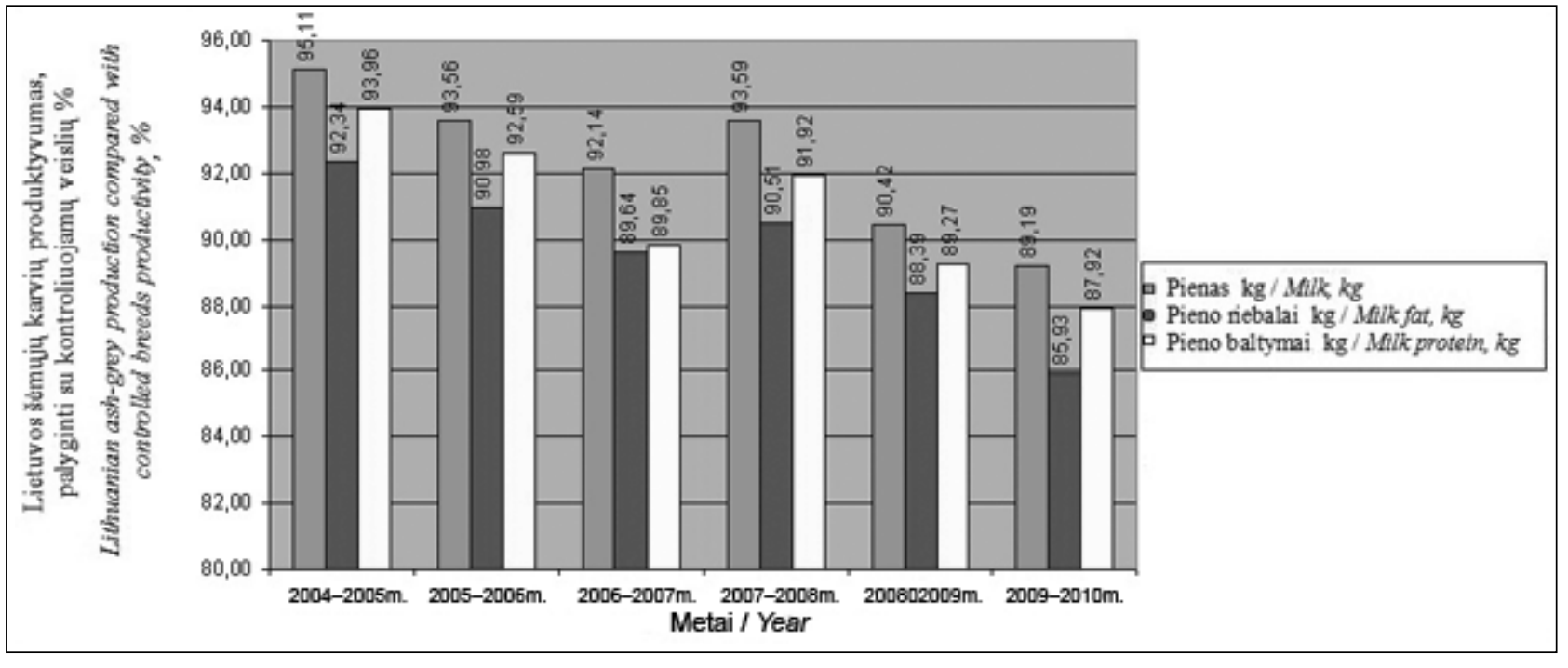

6 pav. Lietuvos šėmujų produktyvumo palyginimas su kontroliuojamų karvių vidurkiu

Fig. 6. Comparison of productivity of Lithuanian Ash-grey controlled cows with average productivity of all controlled $\operatorname{cows}(\%)$

būdingą visų organizmo paveldetų savybiu visumą, kad tiriamuoju laikotarpiu Lietuvos šemujų karvių genotipą (Lietuvos gyvulininkystès institutas, 2011). 2004-2010 m. kontroliuojamų Lietuvos baltnuprimižiai didejo tolygiai - nuo $5131 \mathrm{~kg}$ padidèjo $407 \mathrm{~kg}\left(y=87,371 x+5087,2 ; R^{2}=0,879\right)$

Nors Lietuvos baltnugarių karvių pieningumas analizuojamu laikotarpiu padidèjo $272 \mathrm{~kg}$, tačia

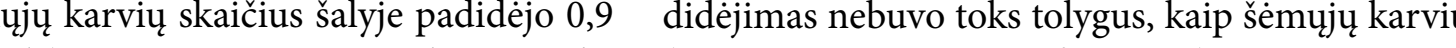
karto (1 lentelè). Tiesinè regresinè analizè parodè, $\quad\left(y=64,829 x+5165,9 ; R^{2}=0,616\right)$
1 lentelè. Lietuvos baltnugarių ir Lietuvos šèmụjų kontroliuojamų karvių produktyvumas (www.vic.lt) Table 1. Productivity of Lithuanian White-backed and Ash-grey controlled cows

\begin{tabular}{|c|c|c|c|c|c|c|c|c|c|c|c|c|}
\hline \multirow{3}{*}{$\begin{array}{l}\text { Metai } \\
\text { Year }\end{array}$} & \multicolumn{6}{|c|}{$\begin{array}{c}\text { Lietuvos baltnugarės } \\
\text { Lithuanian White-backed }\end{array}$} & \multicolumn{6}{|c|}{$\begin{array}{l}\text { Lietuvos šèmosios } \\
\text { Lithuanian Ash-grey }\end{array}$} \\
\hline & \multirow{2}{*}{$\begin{array}{c}\text { Vidu- } \\
\text { tinis } \\
\text { karviu } \\
\text { skaičius } \\
\text { Average } \\
\text { number } \\
\text { of cows }\end{array}$} & \multirow{2}{*}{$\begin{array}{c}\text { Pie- } \\
\text { nas } \\
\text { kg } \\
\text { Milk, } \\
\text { kg }\end{array}$} & \multicolumn{2}{|c|}{$\begin{array}{c}\text { Pieno } \\
\text { riebalai } \\
\text { Fat } \\
\end{array}$} & \multicolumn{2}{|c|}{$\begin{array}{c}\text { Pieno } \\
\text { baltymai } \\
\text { Protein }\end{array}$} & \multirow{2}{*}{$\begin{array}{c}\text { Vidu- } \\
\text { tinis } \\
\text { karviu } \\
\text { skaičius } \\
\text { Average } \\
\text { number } \\
\text { of cows }\end{array}$} & \multirow{2}{*}{$\begin{array}{c}\text { Pie- } \\
\text { nas } \\
\mathbf{k g} \\
\mathrm{Milk}, \\
\mathbf{k g}\end{array}$} & \multicolumn{2}{|c|}{$\begin{array}{c}\text { Pieno } \\
\text { riebalai } \\
\text { Fat }\end{array}$} & \multicolumn{2}{|c|}{$\begin{array}{c}\text { Pieno } \\
\text { baltymai } \\
\text { Protein }\end{array}$} \\
\hline & & & $\%$ & kg & $\%$ & kg & & & $\%$ & kg & $\%$ & kg \\
\hline $\begin{array}{l}2004- \\
2005\end{array}$ & 395 & 5191 & 4,25 & 221 & 3,33 & 173 & 440 & 5131 & 4,23 & 217 & 3,33 & 171 \\
\hline $\begin{array}{ll}2005- \\
2006\end{array}$ & 408 & 5198 & 4,26 & 221 & 3,34 & 174 & 485 & 5232 & 4,24 & 222 & 3,35 & 175 \\
\hline $\begin{array}{l}2006- \\
2007\end{array}$ & 378 & 5506 & 4,21 & 232 & 3,32 & 183 & 431 & 5402 & 4,17 & 225 & 3,29 & 177 \\
\hline $\begin{array}{l}2007- \\
2008\end{array}$ & 391 & 5494 & 4,24 & 233 & 3,33 & 183 & 448 & 5522 & 4,14 & 229 & 3,3 & 182 \\
\hline $\begin{array}{l}2008- \\
2009\end{array}$ & 402 & 5505 & 4,31 & 237 & 3,32 & 183 & 459 & 5533 & 4,26 & 236 & 3,31 & 183 \\
\hline $\begin{array}{l}2009- \\
2010\end{array}$ & 422 & 5463 & 4,37 & 239 & 3,3 & 180 & 477 & 5538 & 4,19 & 232 & 3,29 & 182 \\
\hline
\end{tabular}

Iš pateiktu duomenụ taip pat matome, kad Lie- $\quad 193,7 \mathrm{~kg}$ pieno riebalu ir 144,7 kg pieno baltymu. tuvos baltnugariụ ir šèmujų karviụ pienas yra geros Rezultatai buvo 6-10 \% mažesni už nustatytus sudèties. Pieno riebumas tiriamuoju laikotarpiu mūsų tiriamuoju laikotarpiu.

svyravo nuo 4,14 iki 4,37\%, pieno baltymingumas Lietuvos baltnugares ir šèmosios karvès, palygin $3,29-3,35 \%$ (1 lentelè) ir produktyvumo rodikliai ti su kitų šalių vietinėmis ir nykstančiomis veislè(2 lentelè) pasižymėjo teigiama koreliacija (nuo mis (Sided Tronder and Nordland, Telemark, Dola $0,883$ iki $0,989, \mathrm{p}<0,01)$.

Western Red Polled, Western Fjord, Estonian native,

V. Juškienè (2001) nustate Lietuvos baltnugariu Latvian Blue, Polish Red, Abodance) (7 pav.), yra karviu $(\mathrm{n}=87)$ produktyvumą: pieno $-4577 \mathrm{~kg}$, vidutiniškai nuo 483 iki $2538 \mathrm{~kg}$ pieningesnès. riebumas $-4,28 \%$ ir baltymingumas $-3,24 \%$ arba Latvijos žalụjų (Latvian Brown) ir Lietuvos vie$195,7 \mathrm{~kg}$ pieno riebalų ir 148,3 kg pieno baltymų; tinių karvių primilžiai mažai skiriasi, tačiau LieLietuvos šèmujų $(\mathrm{n}=116)$ : pieno $-4489 \mathrm{~kg}$, rie- tuvos vietinès kontroliuojamos baltnugarès ir šèbumas $-4,32 \%$ ir baltymingumas $-3,22 \%$ arba mosios karvės yra mažiau pieningos (nuo $947 \mathrm{ik}$

2 lentelè. Lietuvos baltnugarių ir Lietuvos šèmụjų kontroliuojamų karvių produktyvumo koreliacijos koeficientai

Table 2. Correlation coefficients of productivity of Lithuanian White-backed and Ash-grey controlled cows

\begin{tabular}{ccc}
\hline $\begin{array}{c}\text { Požymiai } \\
\text { Features }\end{array}$ & $\begin{array}{c}\text { Lietuvos baltnugarės } \\
\text { Lithuanian White-backed }\end{array}$ & $\begin{array}{c}\text { Lietuvos šèmosios } \\
\text { ithuanian Aash-grey }\end{array}$ \\
\hline $\begin{array}{c}\text { Pienas kg-riebalai } \mathrm{kg} \\
\text { Milk, } \mathrm{kg}-\text { fat } \mathrm{kg}\end{array}$ & $0,934^{* *}$ & $0,954^{* *}$ \\
\hline $\begin{array}{c}\text { Pienas } \mathrm{kg}-\text { baltymai } \mathrm{kg} \\
\text { Milk } \mathrm{kg}-\text { protein, } \mathrm{kg}\end{array}$ & $0,989^{* *}$ & $0,986^{* *}$ \\
\hline $\begin{array}{c}\text { Riebalai } \mathrm{kg} \text { - baltymai } \mathrm{kg} \\
\text { Fat, } \mathrm{kg} \text { - protein, } \mathrm{kg}\end{array}$ & $0,883^{* *}$ & $0,975^{* *}$ \\
\hline${ }^{*} \mathrm{p}<0,01$ & &
\end{tabular}




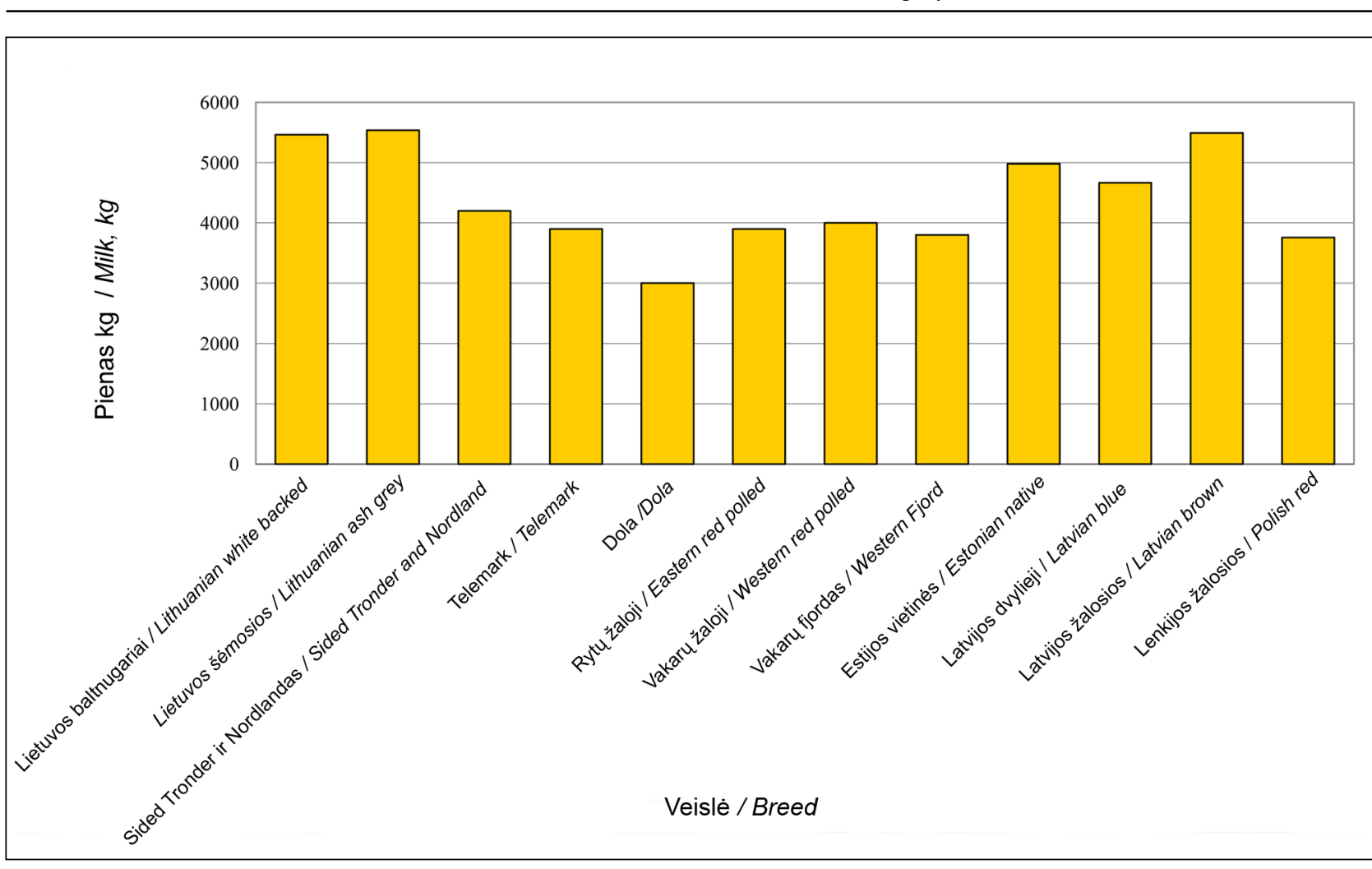

7 pav. Lietuvos baltnugarių ir Lietuvos šèmụjų karvių pieno kg palyginimas su kitų šalių vietinių veislių karvių duodamu pieno kiekiu $2010 \mathrm{~m}$

Fig. 7. Comparison of Lithuanian White-backed and Lithuanian Ash-grey breeds milk (kg) with other countries native breeds (2010)

$3298 \mathrm{~kg}$ ), palyginti su Suomijos ir Danijos vietinémis (Adamczyk, 2008; Agricultural Data Centre; Blacksided nordland; Committee on Farm Animal Genetic Resources, 2002; Domestic Animal Info Estonian Animal Breeding Association; Estonian Animal Recording Centre, 2010; Grinevics, 2010; Hiemstra, 2010; Yearly Milk Enquiry - Online Database; Jemeljanovs, 2004; Kalamess MSc Käde, 2006; Kantanen, 2009; Martyniuk et al., 2011; Nord Gen; Paura et al., 2009; Programy Ochrony Zasobów Genetycznych Zwierząt Gospodarskich; Red Danish; Sæther, 2011; Szarek, 2004; Traditional low producing dairy breeds used as suckler cows, a threat or a future oriented solution).

\section{IŠVADOS}

1. Vietiniai baltnugariai galvijai daugiausia veisiam ar auginami pavieniuose gyvulių augintojų ūkiuose. Po 1-2 karves laiko $67 \%$ baltnugarių karviu augintojų, 3-5 grynaveisles karves prižiūri $26 \%$, o 6-9 grynaveisles karves - tik 7 \% ùkininkų.
2. 66 \% grynaveisliu šèmuju karviu yra laikoma pavieniu gyvulių augintojų ūkiuose (po 1-2 karves). 3-5 grynaveisles karves augina $24 \%$, o 6-9 karves - $9 \%$ ükininkų. 10-12 karvių aptikome tik pas $1 \%$ laikytoju.

3. Lietuvos baltnugariai galvijai sudaro $0,21 \%$, Lietuvos šèmieji $0,25 \%$, palyginti su kitų kontroliuojamų veislių karvèmis.

4. Tiriamuoju laikotarpiu Lietuvos vietinès baltnugarès ir šèmosios karvès, palyginti su šalies kontroliuojamų karvių vidurkiu, atsiliko pieningumu $3,78-12,01 \%$, pieno riebalų produkcija - 5,96$14,07 \%$, pieno baltymų kiekiu - 4,95-13,04 \%.

5. Tolimesnis Lietuvos baltnugarių ir šèmujju karvių produktyvumas iš esmès priklausys nuo efektyvių selekcijos programų ir gerèjančios genetikos.

Gauta 20120405 Priimta 20120630

\section{LITERATŪRA}

1. Adamczyk K., Felenczak A., Jamrozy J., Szarek J., Bulla J. 2008. Conservation of Polish Red Cattle. Slove

2. Agricultural Data Centre. Public Access, Data Selection [žiūrèta 2012-01-03]. Prieiga per internetạ: http://pub.ldc.gov.lv/index.php?lang=en

3. Blacksided Norland [žiurrèta 2012-01-13]. Prieiga per internetą: http://www.embryoplus.com/cattle black_norland.htm

4. Bondesan V. 2011. Supporting local breed conservation through the linkage with traditional products. Socio-economic and Cultural Values of Farm Animal Breeds: Workshop Proceedings. Aas, Norway: NordGen - Nordic Genetic Resource Center. P. 30-31.

5. Breeds of Cows Directory: “L”: Latvian Brown-Luing [žiürèta 2012-01-13]. Prieiga per interneta: http:/ www.moocow.com/info/breedsofcows/l.breedsofcows.shtml

6. Danish Red [žiūrèta 2012-01-11]. Prieiga per interneta: http://www.vic.lt/uploads/file/16_danijos_zalieji.pdt

7. Estonian Animal Breeding Association [žiūrèta 2012-01-12]. Prieiga per interneta: http://www ettl.ee/english/?Native_Cattle_Breed_Society

8stonian Animal Recording Centre. 2010. Results of Animal Recording in Estonia. Kirjastaja: Kirjastu ELMATAR. $52 \mathrm{p}$.

Grgaliūnaite I., Malevičiūte J., Värv S. et al. 2004. Microsatellite Analysis for Making Conservation Priorities among North European Cattle Breeds. in the Baltics. P. 14-17.

10. Grinevics I. 2010. Latvian Blue Cows. Latvijas zilās govis vai No Daugavas izpeld zilā govs. Veterinarais Zurnals. No. 1. P. 42-45.

11. Hall S. J. G., Ruane J. 1993. Livestock breeds and their conservation: a global overview. Cons. Biology. Vol. 7. P. $815-825$.

12. Hiemstra S. J., Haas Y, Mäki A., Gandini T. G. 2010. Local Cattle Breeds in Europe. Development
of Policies and Strategies for Self-sustaining Breeds. Wageningen: Wageningen Academic Publisher. $154 \mathrm{p}$.

13. Yearly Milk Enquiry - Online database [žiürèta 2012-01-12]. Prieiga per internetą: http://www. waap.it/enquiry/

14. Jemeljanovs A. 2004. Selection and Productivity Evaluation of Domestic Animals in Latvia. Animal Breeding in the Baltics. Proceedings of the 10th Baltic Animal Breeding Conference. Tartu, Estonia. P. 267-268.

15. Juškiené V. 2001. Genetic analysis and milk production of Lithuanian Aboriginal Cattle Proceedings of the 7th Baltic Animal Breeding Conference. Tartu: Institute of Animal Science of
Estonian Agricultural University, Estonian Animal Breeding Association, Estonian Animal Breedin Inspectorate. P. 46-48.

16. Juškienè V., Šveistienė R., Juška R. 2003. Lietuvo vietiniu galvijų ūkines-biologines savybes ir priemonès jų genofondo išsaugojimui. Gyvulininkyste mokslo darbai. T. 42. P. 13

17. Kalamess K. 2004. Breeding of Estonian native cows. In: Animal Breeding in Estonia. Tartu, Estonia: OU Paar. P. 25-29.

18. Kantanen J., Olsaker I., Holm L.-E., Lien S Vilkki J., Brusgaard K., Eythorsdottir E., Danell B Adalsteinsson S. 2000. Genetic diversity and population structure of 20 North European cattle breeds. The Journal of Heredity. Vol. 91. No. 6 P. $446-457$.

9. Kaurynienè E. K., Šveistienè R. 2011. Studies of Lithuanian White-backed Cattle Population an their Inbreeding. Tarptautine moksline konferen cija. Veterinarijos ir gyvulininkystes moksly aktualijos. P. 50-51.

. Kontroliuojamu karviu bandy produktyvumo 2008-2009 metu apyskaita. Nr. 72. 6 p.

. Kontroliuojamy karviu bandu produktyvumo 009-2010 metu apyskaita. Nr. 73. 9 p.

Kuosa J. 1980. Lietuvos juodmargiai galvijai. Vilnius. P. 8-14.

J., Tušas S., Boveinienè B. 1999 Immunogenetic characteristics of Lithuanian inGyvulininkste: Ligsto

4. Lieturos gyvulininkystes instituta. Nykstač

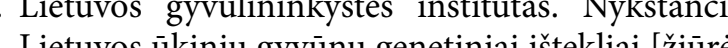
2011-12-03]. Prieiga per interneta http//wwe lgi.lt/pages/skyriai/genf.htm

25. Lietuvos senuju vietiniy žemes

政 programa. 1997. Vilnius.

26. Lietuvos žemès ūkio gyvūnų genetiniai ištekliai - dabartis ir perspektyvos. 2003. Šalies ataskaita FAO organizacijai. Lietuvos žemès ūkio ministerija. P. 22-23.

7. Litwinczuk Z. 2002. Programme of Protection of Polish Whitebacks Cattle Resources. Poland. Lublin. $25 \mathrm{p}$.

28. Malevičiūtè J., Baltrennaitè L., Miceikienè I. 2002 Domestic cattle breed diversity in Lithuania. Veterinarija ir zootechnika. T. 20(42). P. 87-91.

29. Martyniuk E., Sæther N., Krupiński J. 201 Rare native dairy cattle breeds: Quo vadis? Proceedings of the RBI 8th Global Conference on the Conservation of Animal Genetic Resources. Tekirdag, Turkiye. P. 35-41 [žiürèta 2011-12-21]. Prieiga per interneta: http://www.rarebreedsinernational.org/turkey/Martyniuk\%208th\%20 RBI\%20Global\%20Conference.pd

. NordGen-Farm Animal, Telemark Cattle |žiürèt 2012-01-03]. Prieiga per internetą: http://www 
ordgen.org/index.php/en/Farm-Animals/Tema/

Nor-Telemark-cattle

Database [žiūeeta 2012-01-12]. Prieiga per interneta http://www.nordgen.org/husdyrdb/resultat php?KategoriID $=1$ \&langid $=1$

32. Paura L., Jonkus D., Jemeljanova V. 2009. Millk protein k-casein genotypes and milk productivity of Latvian Native breeds. Book of Abstracts of the 60th Annual Meeting of the European Association for Animal Production. Wageningen: Wageningen Academic Publishers. No. 15. 197 p.

33. Programy Ochrony Zasobów Genetycznych Zwierzat Gospodarskich. Bydło Charakterystyka ras. Polska Czerwona [žiürèta 2012-01-13]. Prieiga per interneta: http://www.bioroznorodnosc.izoo.krakow. pl/bydlo/charakterystyka_ras/polska_czerwona

34. Quddus M. A, Amin M. R. 2010. Constraints of native cattle genetic resource conservation and features of breeding system in representative areas of Bangladesh. Journal of the Bangladesh Agricultural University. No. 8(1). P. 113-119.

35. Saether N. 2002. Norway Country Report on Farm Animal Genetic Resources. Committee on Farm Animal Genetic Resources. 71 p

36. Sæther N., Rehnberg A. C. 2011. Traditiona low producing dairy breeds used as suckle Book a threat or a tuture oriented solinion? of the European Federation of Animal Science.
Wageningen: Wageningen Academic Publishers. No. $17.73 \mathrm{p}$.

37. Szarek J., Adamczyk K., Felenczak A. 2004. Polis red cattle breeding: past and present. Animal Genetic Resources Information. Vol. 35. P. 21-35.

38. Šveistienė R., Anskienė L. 2011. Lietuvos baltnugariu galviju selekcinio veislinio darbo programa. Lietuvos nykstančių ūkinių gyvūnų augintojų asociacija. P. 1-19.

39. Šveistienè R., Jatkauskienè V. 2008. Analyses of the genetic diversity within Lithuanian White-Backed cattle. Veterinarija ir zootechnika. T. 44(66). P. 67

40. Šveistys J. 1998. Lietuvos žemès ūkio gyvūnu genetinių ištekliụ išsaugijimas. Gyvūnų veislinin kystės problemos. Tarptautines mokslinés gamybinès konferencijos pranešimu medžiaga. Baisogala. P. $41-43$

41. Tušas S., Miceikiene I., Juškienè V. 2000 Conservation and analysis of Lithuanian indigenous cattle. Proceedings of the 6th Baltic Animal Breeding Conference. Jelgava: Latvia University of Agriculture. P. 9-13.

. Urbšienè D. 2004. Lietuvos vietinių šemų ir baltnugariu karviuu pieningumo ir pieno kokybès palyginimas. Gyvulininkyste: mokslo darbai. P. 71-79. differentition cattle breeds. Animal Breeding in the Baltics. Tartu. P. $111-114$.
Lina Anskienè

ANALYSIS OF LITHUANIAN INDIGENOUS CATTLE PRODUCTION AND DISTRIBUTION

Summary

ithuanian farm animal genetic resources are a nationa treasue, which has a selective, economic, scientific, ecological cultural, historical importance to the Republic of Lithuania and an important part of global biodiversity.

Due to the rapid agricultural development and changes in the market economy, highly productive and specialized agricultural animals and birds supplanted local breeds, an they were on the verge of extinction. Various initiative have been taken to preserve the old livestock breeds from extinction.

The aim of the study was to analyze the distribution and productivity of the Lithuanian native controlled Whitebacked and Ash-grey cows.

According to various programs, holders of the old breeds of animals and birds receive some compensation. This compensation is given to farmers for the losses which they may suffer due to lower productivity of the old breeds, including local White-backed and Ash-grey productivity. However Lithuanian White-backed and Ash-grey prevalence and the number of animal keepers (number of farms) are increasing slightly During the period of 2004-2010 the number of the controlled native White-backed and Ash-grey cows increased by 0.9 times.
The controlled Lithuanian White-backed cows comprise $0.21 \%$ and Ash-grey cows make up $0.25 \%$ as compared with other breeds of controlled cows.

The analysis showed that Lithuanian White-backed an Ash-grey cattle are mostly (66-67\%) found in farms of individual livestock keepers where one or two cows are usually kept. The analysis showed that the productivity of the old of the old breeds of controlled cows grown in Lithuania is lagging behind the popular breeds of cows.

During the study period, the milk yield of Lithuania White-backed cows was lower by $3.78-12.01 \%$, milk fat by $5.96-11.48 \%$ and milk protein content by $4.95-13.04 \%$ as compared with the national average of controlled cows.

The milk yield of Lithuanian Ash-grey controlled cows was by $4.89-10.81 \%$ lower than the average yield of all controlled cows, milk fat was lower by $7.66-14.07 \%$ and mill protein was lower by $6.04-12.08 \%$.

The milk production of Lithuanian Ash-grey cows increased gradually - from 5,131 kg it increased by $407 \mathrm{~kg}$ $\left(y=87.371 x+5,087.2 ; R^{2}=0.879\right)$. The production of Lithuanian White-backed cows analyzed during the period increased by $272 \mathrm{~kg}$, but the increase was not so smooth as that of Lith anian Ash-grey cows $\left(y=64.829 x+5,165.9 ; R^{2}=0.616\right)$.

The productivity of Lithuanian White-backed and Lithuanian Ash-grey cows was compared with other local varieties, closest to Latvian Brown breed cows.

Key words: Lithuanian White-backed, Lithuanian Ashgrey, prevalence, productivity 